FINANCIAL: Jurnal Akuntansi

Published by Program Studi Akuntansi STIE Sultan Agung

Volume 6-Nomor 1, Juni 2020, (98-104)

ISSN-P: 2502-4574, ISSN-E: 2686-2581

Available online at: https://financial.ac.id/index.php/financiaI

\title{
PENGARUH PENGHARGAAN FINANSIAL, PELATIHAN PROFESIONAL, PENGAKUAN PROFESIONAL, DAN PERTIMBANGAN PASAR KERJA TERHADAP PEMILIHAN KARIR AKUNTAN PUBLIK PADA MAHASISWA AKUNTANSI DI PERGURUAN TINGGI SURAKARTA
}

\author{
Rina Ani Sapariyah ${ }^{1)}$, Ika Swasti Putri ${ }^{2}$, Restyandra Lavinia Fujianto ${ }^{3)}$ \\ ${ }^{1,2,3}$ Program Studi Akuntansi Sekolah Tinggi Ilmu Ekonomi Adi Unggul Bhirawa Surakarta \\ E-mail: ${ }^{1}$ rinaanisapariyah2015@gmail.com, ${ }^{2}$ ika@ @stie-aub.ac.id, ${ }^{3}$ restyandra06@gmail.com
}

\begin{abstract}
Abstrak
Berbagai faktor seperti penghargaan finansial, pelatihan profesional, pengakuan profesional dan pertimbangan pasar kerja berpengaruh signifikan terhadap pemilihan karir sebagai akuntan publik dapat berpengaruh terhadap pemilihan karir sebagai akuntan publik. Oleh karena itu, penelitian ini bertujuan untuk memberikan bukti empiris bahwa penghargaan finansial, pelatihan profesional, pengakuan profesional dan pertimbangan pasar kerja berpengaruh signifikan terhadap pemilihan karir sebagai akuntan publik. Beberapa Perguruan Tinggi di Surakarta menjadi tempat bagi penelitian ini dengan populasi mahasiswa Akuntansi di Perguruan Tinggi tersebut. Mahasiswa di UNS, AUB, USB, Pignatelli, UNISRI dan UNIBA dijadikan sebagai sampel penelitian ini dengan jumlah sampel 82 orang. Adapun penelitian ini menghasilkan beberapa hal sebagai berikut. 1) Penghargaan finansial $\left(\mathrm{X}_{1}\right)$ ternyata secara signifikan berpengaruh positif terhadap pemilihan karir akuntan public. 2) Adanya pengaruh positif secara signifikan antara pelatihan profesional $\left(\mathrm{X}_{2}\right)$ dan pemilihan karir akuntan public. 3) Antara variabel $\mathrm{X}_{3}$ (pengakuan profesional) dan pemilihan karir akuntan publik juga terdapat pengaruh yang signifikan.4) Variabel Pertimbangan Pasar Kerja $\left(\mathrm{X}_{4}\right)$ terhadap pemilihan karir akuntan publik ternyata juga memiliki pengaruh yang signifikan. 5) Semua variabel X (independen) memiliki persentase sebesar 80,9\% terhadap pemilihan karir akuntan publik (dependen). Sementara persentase sebesar 19,1\% diwakili oleh variabel lain seperti nilai-nilai intrinsik, nilai-nilai sosial, personalitas, lingkungan kerja dan peran gender.

Kata kunci: Pemilihan karir sebagai akuntan publik, penghargaan finansial pelatihan profesional, pengakuan profesional dan pertimbangan pasar kerja.
\end{abstract}

\section{THE EFFECT OF FINANCIAL AWARDS, PROFESSIONAL TRAINING, PROFESSIONAL RECOGNITION, AND WORKING MARKET CONSIDERATIONS ON SELECTION OF PUBLIC ACCOUNTING CAREER IN ACCOUNTING STUDENTS IN PERGURUAN TINGGI SURAKARTA}

Abstract

Factors such as financial awards, professional training, professional recognition and job market considerations have significant influence on career selection as public accountants can influence career selection as a public accountant. Therefore, this study aims to provide empirical evidence that financial reward, professional training, professional recognition and consideration of the labor market significantly influence the election of a career as a public accountant. Some colleges in Surakarta have been the venue for this study with the student population of accounting at the university. Students in UNS, AUB, USB, Pignatelli, UNISRI and UNIBA serve as samples of this research with a sample number of 82 people. The study resulted in some of the following things. 1) Financial award (X1) turns out to be significantly positive influence on public accountant career selection. 2) A significant positive influence between professional training (X2) and public accountant career selection. 3) The variable X3 (professional recognition) and the selection of the career of public accountants also have significant influence. 4) The work market consideration variable (X4) to public accountant career selection turned out to have a significant influence. 5) All X variables (independent) have a percentage of $80.9 \%$ against the career selection of public accountants (dependent). While a percentage of $19.1 \%$ is represented by other variables such as intrinsic values, social values, personality, working environment and gender roles

Keywords: Career Choice of Public Accountant, Financial Training Reward, Professional Recognition and Employment Market Review.

Article History: Received: 29 Apr 2020 Revised: 10 Mei 2020 Accepted: 28 Mei 2020 


\section{PENDAHULUAN}

Seorang mahasiswa tentunya ingin memiliki jenjang karir yang menjadi sesuai dengan jurusan mereka tekuni selama menimba ilmu di Universitas. Contohnya adalah mahasiswa dari jurusan Akuntansi yang menjadi seorang akuntan publik karena mendapatkan disiplin ilmu yang sesuai dengan jenjang perkuliahan. Ketika memilih jenjang karir, mahasiswa seharusnya tidak hanya berpatokan pada minat dan kesesuaikan jurusan saja, akan tetapi juga memikirkan tanggung jawab yang akan dihadapi ketika memutuskan memilih profesi tersebut, termasuk ketika seorang mahasiswa memilih akuntan publik sebagai profesi yang akan dijalaninya. Departemen Keuangan Pusat Akuntansi dan Penilaian Layanan (PPAJP) merilis data bahwa Indonesia ternyata masih kekurangan tenaga akuntan publik. Pada tahun 2012, Indonesia sebenarnya masih membutuhkan 200.000 tenaga Akuntan publik jika dibandingkan dengan total penduduk pada saat itu yang mencapai 230.000.000 (Suyono, 2014).

$$
\text { Survei tersebut dilakukan }
$$

mengingat bahwa kuantitas akuntan publik di Indonesia masih tertinggal dibandingkan anggota ASEAN. Pada tahun yang sama, jumlah akuntan publik di Thailand mencapai 6.000 akuntan, Filipina memiliki 4.941 akuntan dan Malaysia memiliki 2.500 akuntan. Sementara itu, Indonesia hanya memiiki 1.000 akuntan pada saat itu, ini menunjukkan bahwa kuantitas akuntan publik di Indonesia masih tertinggal dengan negara-negara ASEAN. Jika hal itu terus terjadi maka profesi akuntan publik di Indonesia akan diisi oleh Tenaga Kerja Asing (TKA) yang akan berbanding lurus dengan mundurnya kuantitas dan kualitas tenaga akuntan publik di Indonesia.

Copyright (C) 2020, FINANCIAL: Jurnal Akuntansi

\section{LANDASAN TEORI}

Karir merupakan suatu proses pengembangan jenjang kerja yang mencakup memilih, memilah, melakukan pekerjaan, mendapatkan gaji, dan pensiun. Dengan kata lain, pengembangan jenjang kerja juga disebut sebagai pengembangan karir. Karir juga merupakan segala tingkah laku dan relasi yang berkaitan dengan usaha untuk meningkatkan kualitas dalam kinerja seseorang di tempat kerja (Gibson et al. 1995). Pernyataan ini diperkuat oleh Irianto (2001) yang menyatakan bahwa karir dapat dikaji dalam dua dimensi, yaitu elemen subjektif dan objektif. Kemampuan seorang pekerja dalam mengubah pandangan objektif di lingkungan kerjanya menjadi lingkungan subjektif yang menguntungkan dirinya dapat disebut sebagai elemen subjektif, sementara kemampuan pekerja meningkatkan status atau kedudukan dalam tempat kerja sesuai dengan kinerja yang ia tunjukkan ke atasan bisa digolongkan sebagai elemen objektif. Ini juga diperkuat oleh Nuraini (2013) yang menafsirkan pengembangan karir sebagai proses peralihan atau pembaharuan tanggung jawab lebih tinggi daripada sebelumnya sebagai dampak yang ditimbulkan karena kinerjanya yang memuaskan.

Jika ditinjau dari Undang Undang no. 5 tahun 2011 dan Keputusan Menteri Keuangan nomor 17/PMC.01/2008, akuntan publik dapat disebut sebagai orang yang bekerja memublikasikan layanan akuntansi dan memiliki izin layanan yang digunakan untuk melayani akuntansi untuk publik. Dalam pekerjaannya, seorang akuntan bekerja di kantor akuntan dan dapat diklasifikasikan menjadi dua, yaitu auditor laporan keuangan dan konsultan keuangan. (Wijayanti, 2011). Pendapat ini 
juga didukung oleh pendapat dari Muladi (dalam Octavia, 2006) yang berpendapat bahwa penelitian laporan keuangan merupakan aspek yang dijual oleh seorang akuntan professional. Adapun pihak yang menjadi target penjualan kebanyakan adalah investor, kreditor, calon pemberi pinjaman, calon investor dan instansi pemerintah (khususnya otoritas pajak). Seorang akuntan publik dituntut memiliki kredilitas yang mumpuni dalam bidang pengelolaan keuangan, selain itu seorang akuntan publik harus memiliki latar belakang pendidikan yang relevan dengan bidang yang ditekuni dan harus memiliki izin dari Menteri Keuangan dalam membuka jasa akuntan publik.

Terkait dengan jenjang kerja, adanya gaji atau imbalan tidak bisa dilepaskan dari hal tersebut. Menurut Mulyadi (2011) gaji merupakan suatu pembayaran atas layanan yang dilakukan oleh karyawan kepada perusahaan. Pernyataan tesebut dipertegas oleh pernyataan dari Soemarso (2009) yang menyatakan bahwa penghargaan yang diberikan kepada karyawan sebagai balas jasa yang ditetapkan secara bulanan bisa juga disebut sebagai gaji. Gaji bisa juga berarti pembayaran yang dilakukan perusahaan kepada karyawan sebagai bentuk pembayaran hak atas kinerjanya selama di perusahaan. (Mardi, 2011). Hasibuan (2002) memiliki pendapat bahwa gaji menunjuk pada remunerasi yang diberikan secara berkala sebagai jaminan bagi karyawan untuk meningkatkan kinerjanya dalam perusahaan. Dengan kata lain, gaji diberikan sebagai balas jasa sekaligus remunerasi bagi karyawan agar lebih termotivasi sekaligus sebagai bentuk timbal balik dari layanan yang diberikan kepada perusahaan.

Copyright (C) 2020, FINANCIAL: Jurnal Akuntansi
Berkaitan dengan peningkatan kinerja, keterampilan dari karyawan merupakan suatu hal yang perlu ditingkatkan. Keterampilan yang mengalami peningkatan akan berbanding lurus dengan pengakuan sosial di tempat kerja. Pengakuan tersebut menjadi salah satu indikator peningkatan motivasi kerja di samping pemberian remunerasi sebagai penunjang motivasi dalam bekerja (Trirorania, 2004). Pelatihan diidentifikasi menjadi empat tahapan, yaitu pelatihan sebelum bekerja, pelatihanan di luar lembaga untuk meningkatkan profesional, pelatihan reguler di institusi, dan mendapatkan berbagai pengalaman kerja. Pelatihan sebelum bekerja dilakukan untuk meningkatkan ketermpilan seorang calon akuntan publik sebelum terjun ke dunia kerja yang sebenarnya. Pelatihan ini dianggap paling penting karena menjadi titik tolak memulai profesi akuntan publik. Pelatihan di luar lembaga menjadi pelatihan yang penting untuk dilakukan karena terdapat beberapa permasalahan berkaitan dengan akuntansi yang tidak ditemukan di pelatihan sehingga dibutuhkan peningkatan kemampuan dari luar pelatihan. Pelatihan reguler di institusi dibutuhkan untuk mendapatkan pengetahuan dasar dari lembaga yang terpercaya. Setelah itu, akuntan publik akan mendapatkan berbagai pengalaman pembelajaran sehingga memungkinkannya untuk mendapatkan kompetensi yang lebih sekaligus pengakuan prestasi dan pencapaian yang akan menunjang kinerja. Ini tidak lepas dari para calon akuntan publik yang berpikir bahwa pelatihan yang dipilih ini akan meningkatkan kompetensi dan membuka kemungkinan untuk melakukan pekerjaan di bidang lain (Rahayu, 2003). 
Pemilihan karir sebagai akuntan publik memiliki keterkaitan erat dengan peghargaan finansial. Penghargaan finansial tersebut dipertimbangkan dalam pemilihan profesi karena tujuan utama seseorang bekerja adalah memperoleh penghargaan finansial. Menurut Benny dan Yuskar (2006), profesi akuntan publik merupakan salah sau profesi yang tergolong sebagi profesi termahal karena sumber pendapatan terbesar dari akuntan publik telah bergeser dari jasa audit ke jasa konsultasi manajemen. Pelatihan profesioanl juga memiliki pengaruh erat terhadap pemilihan karir akuntan publik karena pelatihan profesional merupakan pelatihan yang diberikan guna untuk peningkatan kemampuan dan keahlian suatu profesi, tidak hanya itu pelatihan profesional juga merupakan suatu persiapan dan pelatihan yang harus dilakukan sebelum memulai sebuah karir (Rahayu, 2003). Pengakuan profesional berpengaruh terhadap pemilihan karir karena Merdekawati (2011) dalam penelitiannya menyatakan bahwa adanya pengaruh presepsi mengenai pengakuan profesional dalam suatu bidang karir akuntan yang nampaknya menjadi salah satu faktor yang mempengaruhi mahasiswa untuk memilih karir. Selain itu, pertimbangan pasar kerja juga memiliki pengaruh terhadap karir karena salah satu pertimbangan kerja adalah keamanan kerja. Keamanan kerja merupakan faktor dimana karir yang dipilih dapat bertahan dalam jangka waktu yang cukup lama. Karir yang diharapkan bukan pilihan karir sementara, akan tetapi harus dapat terus berlanjut sampai seseorang nantinya pensiun.

\section{METODE PENELITIAN}

\section{Lokasi Penelitian}

Beberapa sekolah dan Universitas Negeri dijadikan oleh peneliti sebagai lokasi objek penelitian karena sesuai dengan kebutuhan penelitian ini.

\section{Populasi dan Sampling}

Sekumpulan objek yang dijadikan oleh peneliti sebagai suatu aspek yang dipelajari dan diambil kesimpulannya dapat disebut sebagai populasi, sedangkan bagian dari populasi yang diambil sebagai bagian dari penelitian disebut juga sampel (Sugiyono, 2010). Sekumpulan mahasiswa akuntasi dan siswa dari beberapa sekolah dijadikan sebagai objek dari penelitian ini. Metode sampling bertarget dalam penelitian ini dijadikan sebagai metode pengambilan sampel yang paling relevan. Jumlah sampel yang digunakan dalam penelitian ini adalah 82 orang sesuai dengan teori Supranto bahwa sampel minimal harus 30 sampel ( $\mathrm{n}>30)$.

\section{Metode Pengumpulan Data}

Penyebarluasan kuesioner, penelitian Perpustakaan dan akses ke situs web dan situs web menjadi cara bagi peneliti untuk mengumpulkan data yang diperlukan untuk penelitian ini.

\section{Metode Analisis Data}

Uji Hipotesis dan Uji Kualitas Data diperlukan sebagai penguji untuk data yang akan digunakan dalam penelitian ini.

a. Uji Kualitas Data

Uji kualitas atau tes validitas diitujukan untuk mengukur legalitas atau ketiadaan kuesioner. Dinyatakan bahwa "kuesioner tersebut sah jika pertanyaan dalam kuesioner dapat mengidentifikasi survei yang akan diukur dengan kuesioner" (Suyono, 2011). Perhitungan dibuat 
menggunakan program SPSS (Statistik untuk ilmu sosial).

b. Uji Hipotesis

1) Regresi Linier Berganda

Untuk mengetahui pengaruh antar variabel dalam penelitian ini, maka digunakan regresi jenis ini dengan rumus sebagai berikut.

$\mathrm{Y}=\alpha+\beta 1 \mathrm{X} 1+\beta 2 \mathrm{X} 2+\beta 3 \mathrm{X} 3+\beta 4 \mathrm{X} 4+\mathrm{e}$

2) Uji T

Hasil uji $\mathrm{T}$ dapat dilihat pada aplikasi SPSS. Hasil signifikansi kurang dari 0,05 menunjukkan adanya pengaruh yang signifikan (sig < 0,05), jika signifikansi lebih dari 0,05 maka tidak ada pengaruh yang signifikan antar variabel $(\mathrm{sig}>0,05)$.

3) Koefisien Determinasi

Koefisien Determinasi adalah nilai yang menggambarkan keseluruhan perubahan dalam persamaan regresi $\mathrm{Y}$ (variabel dependen). Nilai ini dengan definisi mencerminkan seberapa besar perubahan dalam variabel dependen dapat dijelaskan oleh variabel independen. Jika rasio determinan adalah 0 , variasi variabel dependen tidak dapat dijelaskan oleh variabel independen. Sebaliknya, jika rasio determinan adalah 1, semua variabel dependen dapat dengan sempurna dijelaskan oleh variabel independen.

\section{HASIL DAN PEMBAHASAN}

\section{Analisis Regresi Linier Berganda}

Regresi Linear Berganda yang ditemukan berdasarkan hasil perhitungan ssesuai rumus pada metode adalah sebagai berikut.

$$
\begin{gathered}
Y=7,166+0,084\left(X_{1}\right)+0,417\left(X_{2}\right)+ \\
0,070\left(X_{3}\right)+0.112\left(X_{4}\right)
\end{gathered}
$$

Rumus tersebut menggambarkan hubungan Y (pemilihan profesi akuntan publik) dengan variabel independen yang lain $\left(\mathrm{X}_{1}\right.$, $\mathrm{X}_{2}, \mathrm{X}_{3}, \mathrm{X}_{4}$ ).

\section{Hasil Uji t}

Hasil uji t memperlihatkan bahwa pengaruh yang signifikan dengan signifikansi 0,009 ditemukan pada penghargaan finansial terhadap pemilihan karir akuntan publik. Pengaruh signifikan juga ditemukan dalam pengaruh pelatihan profesional dengan signifikansi 0,000. Variabel lain yang memiliki pengaruh terhadap pemilhan karir akuntan publik adalah pengakuan profesional dengan signifikansi 0,019. Variabel terakhir yang berpengaruh terrhadap pemilihan karir sebagai akuntan publik adalah pertimbangan pasar kerja dengan signifikansi 0,005. Keempat variabel tersebut memenuhi syarat karena kurang dari $0,05(<0,05)$ sehingga berpengaruh positif. Penelitian ini didukung dengan penelitian Suyono (2014)

\section{Koefisisen Determinasi}

Berdasarkan tabel uji koefisien determinasi menunjukkan nilai koefisien determinasi sebesar 0,809 yang berarti menandakan pengaruh yang diberikan oleh variabel independen $\left(\mathrm{X}_{1}, \mathrm{X}_{2}, \mathrm{X}_{3}, \mathrm{X}_{4}\right)$ terhadap variabel dependen (Y) sebesar $80,9 \%$ dan sisanya $19,1 \%$ dipengaruhi oleh variabel lain yang tidak termasuk dalam penelitian ini.

\section{SIMPULAN DAN SARAN}

\section{Simpulan}

Serangkaian pengujian yang dilakukan dalam penelitian ini menghasilkan hasil sebagai berikut.

1. Penghargaan finansial $\left(X_{1}\right)$ ternyata secara signifikan berpengaruh positif terhadap pemilihan karir akuntan publik

2. Adanya pengaruh positif secara signifikan antara pelatihan profesional 
$\left(\mathrm{X}_{2}\right)$ dan pemilihan karir akuntan publik

3. Antara variabel $\mathrm{X}_{3}$ (pengakuan profesional) dan pemilihan karir akuntan publik juga terdapat pengaruh yang signifikan

4. Variabel Pertimbangan Pasar Kerja $\left(\mathrm{X}_{4}\right)$ terhadap pemilihan karir akuntan publik ternyata juga memiliki pengaruh yang signifikan

5. Semua variabel $X$ (independen) memiliki persentase sebesar $80,9 \%$ terhadap pemilihan karir akuntan publik (dependen). Sementara persentase sebesar $19,1 \%$ diwakili oleh variabel lain.

\section{Saran}

Saran yang dapat diajukan sesuai dengan hasil penelitiaan adalah sebagai berikut.

1. Peneliti menyarankan bahwa imbalan keuangan hendaknya meningkatkan potensi kenaikan upah dan memberikan gaji sejalan dengan pendidikan.

2. Peneliti menyarankan bahwa pelatihan harus ditingkatkan, misalya dengan meningkatkan pelatihan pra-kerja.

3. Pengakuan terhadap prestasi hendaknya diberikan sebagai bentuk pengakuan profesonalitas kinerja

4. Proses mengakses lowongan pekerjaan hendaknya dipermudah sebagai bentuk perbaikan pasar kerja

5. Diperlukan penambahan berbagai aspek dalam penelitian seperti variabel, populasi, dan sampel.

\section{DAFTAR PUSTAKA}

Benny, E., \& Yuskar. (2006). Pengaruh $\begin{array}{llr}\text { Motivasi } & \text { Terhadap } & \text { Minat } \\ \text { Mahasiswa } & \text { Akuntansi } & \text { Untuk } \\ \text { Mengikuti } & \text { Pendidikan } & \text { Profesi } \\ \text { Akuntansi } & \text { (PPAk), Simposium } \\ \text { Nasional Akuntansi IX. } & \end{array}$
Gibson, et.al. (1995). Organisasi: Perilaku, Struktur dan Proses. Jakarta: Erlangga.

Hasibuan, Malayu S.P. (2002). Manajemen Sumber Daya Manusia. Jakarta: Bumi Aksara.

Irianto, J. (2001). Tema-Tema Pokok Manajemen Sumber Daya Manusia. Surabaya: Insan Cendekia

Mardi. (2011). Sistem Informasi Akuntansi. Jakarta: Ghalia Indonesia.

Merdekawati, Dian. (2011). Faktor-faktor yang Mempengaruhi Pemilihan Karir Akuntan Publik dan Non Akuntan Publik. Jurnal Ekonomi, 13(1), 1-7

Mulyadi. (2011). Auditing. Jakarta: Salemba Empat.

Nuraini. (2013). Presepsi Mahasiswa Akuntansi Mengenai Faktor-Faktor yang Mempengaruhi Pemilihan Karir sebagai Akuntan Publik dan Non Akuntan Publik (Studi Kasus Pada Mahasiswa Akuntansi Kelas Sore

Universitas Semarang). Jurnal Fenomena. Rahayu, Sri. (2003). Presepsi Mahasiswa Akuntansi Mengenai Faktor-faktor yang Mempengaruhi Pemilihan Karir. Simposium Nasional Akuntansi VI.

Soemarso, S.R. (2009). Akuntansi Suatu Pengantar. Jakarta: Salemba Empat Sugiyono. (2010). Statistika untuk Penelitian. Bandung: Alfabeta.

Suyono, Nanang Agus. (2014). Analisis Faktor-faktor yang Mempengaruhi Pemilihan Karir seabagai Akuntan Publik (Studi Kasus Pada Mahasiswa Akuntansi UNSIQ). Skripsi, tidak dipublikasikan. Universitas Sains Al Qur'an

Wijayanti, Lilies Endang. (2011). FaktorFaktor yang Mempengaruhi Pemilihan Karir Akuntan Publik. Jurnal Media Mahardika, 10 (1), 11 


\section{PROFIL SINGKAT}

Rina Ani Sapariyah, lahir di Boyolali 23 Juni 1963. Pendidikan terakhir Magister Manajemen Universitas Muhamadiyah Surakarta Tahun 2004 dan sekarang bekerja sebagai dosen tetap di STIE Adi Unggul Bhirawa Surakarta.

Ika Swasti Putri, lahir di Surakarta 21 Oktober 1986. Pendidikan terakhir Magister Akuntansi Tahun 2018. Profesi sebagai dosen tetap di STIE Adi Unggul Bhirawa Surakarta.

Restyandra Lavinia Fujianto lahir di Karanganyar 6 Oktober 1992, Pendidikan terakhir Sarjana Akuntansi di STIE Adi Unggul Bhirawa Surakarta. 